\title{
PELATIHAN PENGECORAN LIMBAH ALUMINIUM RUMAH TANGGA UNTUK MENINGKATKAN NILAI JUAL BAGI MASYARAKAT DI KABUPATEN MADIUN
}

\author{
Eko Budi Santoso ${ }^{1}$, Eva Hertnacahyani Herraprastanti ${ }^{2}$ \\ ${ }^{1}$ Politeknik SAKTI Surabaya. Email: azizankoe@gmail.com \\ 2STT Ronggolawe Cepu. Email: ev.hertna@gmail.com
}

\begin{abstract}
The purpose of this activity is to conduct training for the community, especially from around Madiun, to be able to do aluminum waste treatment by doing re-casting to be printed into a craft that is worth selling. Re-casting in this activity uses the simplest tool in the hope that it can be reached by the target community. This casting can be done by using a simple kitchen by using a fire furnace with combustion using LPG. The training activity was held for 2 (two) days, with the details of the first day in the form of material about metals and casting while the second day was carried out by the practice. The results of this activity are in creasing knowledge about metals, especially aluminum and knowledge of simple casting practices.
\end{abstract}

Keywords: Waste, aluminum, casting, sand mold

\begin{abstract}
ABSTRAK
Tujuan dari kegiatan ini adalah melakukan pelatihan kepada masyarakat khususnya dari sekitar Madiun agar dapat melakukan pengolahan limbah aluminium dengan melakukan pengecoran ulang untuk di cetak menjadi kerajinan yang layak jual. Pengecoran ulang dalam kegiatan ini menggunakan alat yang paling sederhana dengan harapan bisa dijangkau oleh masyarakat kalayak sasaran. Pengecoran ini dengan menggunakan dapur sederhana dengan menggunakan tungku api dengan pembakaran menggunakan LPG. Kegiatan pelatihan ini dilaksanakan selama 2 (dua) hari, dengan rincian hari pertama berupa materi tentang logam dan pengecoran sedang hari kedua adalah dengan pelaksanaan praktek. Hasil dari kegiatan ini adalah bertambahnya pengetahuan mengenai logam khususnya aluminium dan pengetahuan praktek pengecoran sederhana.
\end{abstract}

Kata Kunci: Limbah, aluminium, pengecoran, cetakan pasir

\section{PENDAHULUAN}

Kabupaten Madiun merupakan salah satu kota yang berkembang di Jawa Timur yang dipengaruhi oleh faktor geografi dan faktor ekonomis. Kota ini berada pada pertigaan jalur lintas jalan arteri primer menghubungkan Provinsi Jawa Timur dan Jawa Tengah, sehingga banyak komoditi yang dihasilkan dari kota ini yang tentu saja berdampak pada menumpuknya sampah. Volume sampah yang dihasilkan oleh warga Kota Madiun, Jawa Timur, dan masuk ke Tempat Pembuangan Akhir (TPA) Winongo setiap tahunnya terus meningkat hingga saat ini mencapai 110 ton per hari (madiun.solopos.com) 
Menurut Dinas Lingkungan Hidup (DLH) Kota Madiun mencatat jumlah produksi sampah yang masuk ke TPA Winongo yang berada di Kelurahan Winongo, Kecamatan Manguharjo, pada tahun 2016 mencapai 91,1 ton per hari. Sedangkan pada akhir November 2018 telah meningkat menjadi 100 ton per hari, dan sekarang telah mencapai 110 ton per hari. Kepala Dinas Lingkungan Hidup Kota Madiun, Suwarno menjelaskan dari 110 ton sampah yang masuk ke TPA setiap hari didominasi oleh sampah rumah tangga. Selain sampah organik, sampah plastik juga terpantau cukup banyak. Peningkatan sampah disebabkan jumlah penduduk Kota Madiun yang juga bertambah seiring dengan perkembangan perekonomian daerah setempat. Pemerintah Madiun terus berupaya meminimalisir meningkatnya sampah, salah satunya dengan melakukan daur ulang terhadap sampah yang masuk. Adapun, sampah-sampah organik didaur ulang menjadi gas metan yang dapat digunakan sebagai bahan bakar alternatif bagi sekitar $150 \mathrm{KK}$ yang ada di sekitar TPA. Selain itu, sampah organik juga diolah menjadi kompos dan pupuk organik. Sedangkan sampah plastik didaur ulang menjadi minyak plastik, serta dipilah dan diolah menjadi aneka produk kerajinan tangan bernilai ekonomi tinggi. Pengelolaan sampah plastik menjadi produk kerajinan melibatkan ibuibu PKK pengelola bank sampah di tiap kelurahan. Sejauh ini sudah ada sekitar 43 bank sampah yang tersebar di 27 kelurahan dan 104 bank sampah di sekolah-sekolah baik tingkat SD, SMP, hingga SMA (Republika.co.id).

Sedangkan limbah aluminium yang banyak ditemui di sekitar Madiun dalam bentuk kaleng minuman, komponen elektronik, perabot rumah tangga, beberapa jenis bahan bangunan dan bahkan beberapa jenis makanan menggunakan aluminium foil belum tertangani. Limbah aluminium termasuk jenis limbah non organik yang tidak bisa diuraikan oleh proses biologi. Limbah kaleng yang tertimbun di dalam tanah akan sulit sekali terurai, sehingga memicu terjadinya korosif atau karat. Kaleng yang korosif ini akan mengandung beberapa logam berat yang nantinya bisa terbawa ke dalam air tanah. Logam-logam berat seperti magnesium atau kalium yang berasal dari kaleng berkarat tersebut umumnya tidak bisa dicerna oleh tubuh dan akan tertimbun, seperti halnya kalium yang bisa mengendap di tulang. Kaleng yang tertimbun di dalam tanah, akan bersentuhan dengan kandungan asam yang terdapat di tanah. Asam-asam tersebut akan bereaksi dengan kaleng dan menimbulkan karat. Untuk kaleng yang terbuat dari alumunium membutuhkan waktu yang lebih lama untuk berkarat. Tapi jika kaleng yang biasa, maka waktunya sangat cepat bahkan dalam waktu satu hari kaleng tersebut sudah berkarat (www.detik.com)

Terinspirasi dari sulitnya limbah aluminium terdegradasi dan tidak bisa diuraikan oleh proses biologi di lingkungan, maka aluminium yang sudah terbuang atau tidak terpakai berpotesi untuk dimanfaatkan kembali. Beberapa pihak mencoba melakukan berbagai percobaan untuk mencari solusi memanfaatkan limbah dari aluminium. Mendaur ulang sampah aluminium dapat menghemat 5\% dari energi dari pada memproduksi aluminium dari bauksit (Suyitno, 2016).

Aluminium merupakan logam yang mudah diolah, karena sifatnya yang cukup lembut, kuat, dan ringan. Pengolahan aluminium sebelumnya telah banyak digunakan pada era 1920-an dan 1960-an dimana pada era tersebut perkembangan teknologi dan 
ide-ide futuristik mulai bermunculan. "Today is a particular time of fusion between industry and craft, between material and digital" (Freya, 2014). Sehingga dapat dikatakan bahwa pada era ini, material baik bidang industri, teknologi, craft, maupun yang lainnya, dapat digabungkan untuk menghasilkan sebuah karya tertentu.

Berdasarkan latar belakang limbah aluminium yang belum banyak dimanfaatkan di Kota Madiun, penulis terinspirasi untuk mengembangkan pemanfaatan aluminium dengan inovasi baru berupa pengecoran ulang menjadi produk souvenir. Suyitno, (2016) pada kegiatan pengabdian masyarakat pada IKM mitra adalah menggunakan teknologi cetakan yang terbuat dari besi. Cetakan ini menggantikan bahan pasir dan cetakan pasir. Dengan demikian, proses pengecoran menjadi lebih cepat karena hanya membuat satu cetakan untuk produk yang sama dan berjumlah banyak. Hasilnya menunjukkan bahwa penerapan teknologi tersebut menghasilkan produk dengan presisi dan konsisten dalam bentuk dan ukuran.

Tujuan dari kegiatan ini adalah melakukan pelatihan kepada masyarakat khususnya dari sekitar Madiun agar dapat melakukan pengolahan limbah aluminium dengan melakukan pengecoran ulang. Pengecoran ulang dalam kegiatan ini menggunakan alat yang paling sederhana dengan harapan bisa dijangkau oleh masyarakat kalayak sasaran. Pengecoran ini bisa dilakukan dengan menggunakan dapur sederhana dengan menggunakan tungku api dengan pembakaran menggunakan LPG. Metode pengecoran yang digunakan menggunakan pengecoran tuang (grafity casting) dan dengan cetakan pasir resin. Dari hasil pengecoran ulang ini dicetak dalam bentuk barang yang layak jual misalnya souvenir berupa gantungan kunci sederhana dan juga spare part untuk mesin pertanian.

\section{METODE PELAKSANAAN}

Kegiatan pengabdian kepada masyarakat ini dilakukan dalam bentuk pelatihan pengecoran aluminium baik melalui teori maupun praktek. Pelatihan ini bertujuan agar mitra menjadi lebih memahami dalam pemanfaatan limbah alumunium sehingga menjadi lebih bermanfaat dan bernilai jual. Metode pelaksanaan pelatihan ini dilakukan ada beberapa langkah, yaitu: Langkah 1 Sosialisasi yaitu tim pengabdi memberikan sosialisasi mengenai pemanfaatan limbah alumunium menjadi material yang bernilai jual tinggi. Langkah 2 dengan Pemberian Teori mengenai Sifat sifat Logam dan non logam, Ciri, Sifat serta Manfaat Aluminium, dan Teknik Pengecoran Aluminium dengan cetakan pasir. Langkah 3 Pelaksanaan Praktek Pengecoran Tim pengabdi bersama mitra mempraktikkan mengecor ulang limbah alumunium menjadi material yang bernilai jual tinggi. Yang terpenting dalam pelatihan ini adalah cara menumbuh kembangkan minat berwirausaha dan mengembangkan bakat melalui ide-ide kreatif dan inovatif untuk dapat menangkap peluang serta kesempatan, khususnya dalam industri mikro yang berbahan dasar aluminium dari limbah rumah tangga.

Adapun tahapan Kegiatan Pelatihan Pengabdian Kepada Masyarakat ini dapat dilihat pada gambar berikut ini 


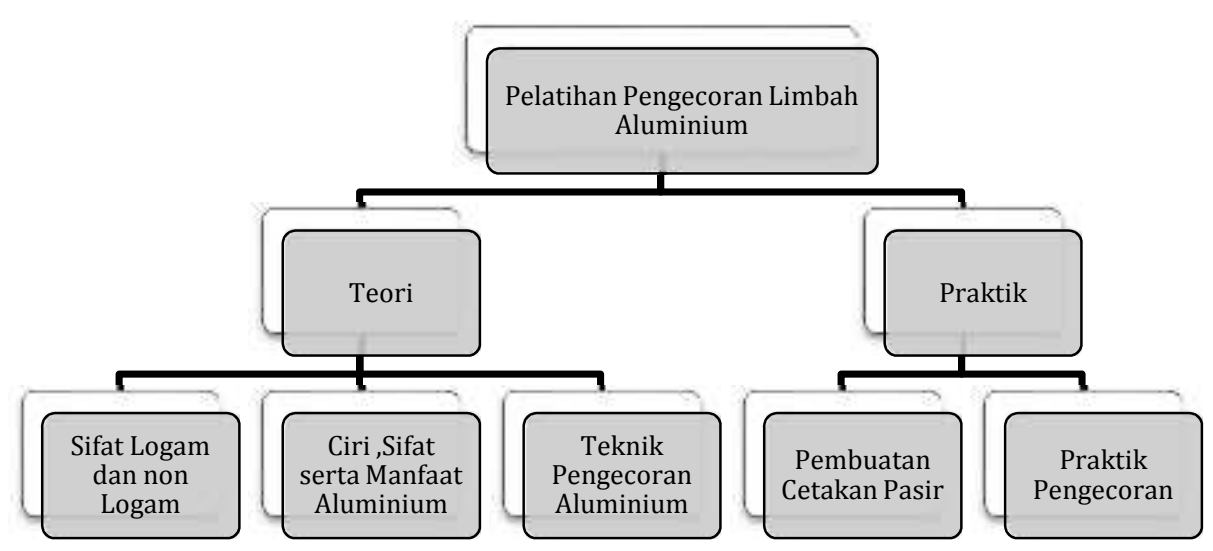

Gambar 1. Tahapan Pelatihan Pengecoran Limbah Alumunium

\section{Lokasi dan waktu Kegiatan}

Kegiatan pengabdian kepada masyarakat (PKM) berupa pelatihan pengecoran aluminium dilakukan di Rumah Makan Utama, Caruban-Madiun. Adapun peserta adalah kelompok masyarakat usia produktif yang berada di sekitar Caruban yang tidak dibedakan berdasarkan latar belakang pendidikan, usia maupun daearah asal. Data jumlah peserta pelatihan secara keseluruhan berjumlah 20 orang yang terdiri dari remaja usia produkti.

Adapun waktu pelatihan pengecoran aluminium ini dilakukan selama 2 (dua) hari, dimana hari pertama diberikan teori berupa Pengenalan Jenis Logam Aluminium, Karakteristik Logam Aluminium serta persiapan alat untuk praktek. Sedangkan hari berikutnya praktek pengecoran serta pencetakan aluminium pada matras sederhana. Pada akhir kegiatan pelatihan diberikan waktu untuk bertanya jawab mengenai kegiatan yang telah dilakukan.

\section{HASIL DAN PEMBAHASAN}

Dari kegiatan terdahulu metoda pemanfaatan aluminium skrap sebagai bahan baku industri Kecil Pengecoran Logam Non Ferro melalui perlakuan pada logam cair (solution treatment) dengan Rotary Degasser. Untuk memproduksi coran komponen otomotif (1) terlebih dahulu dipilih bahan yang tidak tercampur dengan bahan-bahan lain; (2) menggunakan dapur krusibel yang terbuat dari grafit dan burner pemanas yang mampu melebur bahan dengan sempurna; (3) pengendalian temperatur peleburan dengan menggunakan alat pengukur suhu (termocouple) dan mempertahankan suhu peleburan pada $725^{\circ} \mathrm{C}$ karena diatas suhu tersebut aluminium banyak menghasilkan gas $\mathrm{H}$ yang berakibat porus pada hasil coran; (4) dilakukan perlakuan-perlakuan pada logam cair (solution treatment), perlakuan logam cair (solution treatment) dengan cara degassing menggunakan alat rotary degasser yang memberikan peningkatan sifat mekanik terbesar adalah pengadukan selama 2,5 menit, untuk perbaikan butir yang memberikan peningkatan tertinggi adalah dengan penambahan Ti (sebagai TiB) pada penambahan $0,05 \%$, sedangkan untuk modifikasi yang memberikan peningkatan 
tertinggi adalah dengan penambahan Coveral 11 pada penambahan 0,07\% (Budiyono, A. 2013)

Sedangkan kegiatan pengabdian masyarakat ini tidak spesifik menggunakan metode tertentu tetapi menggunakan metode sederhana yang juga memanfaatkan peralatan yang benyak tersedia di masyarakat. Dengan adanya kegiatan ini diharapkan antara peserta dan penulis terjadi transfer knowledge sehingga di waktu mendatang akan bisa membawa dampak perubahan terhadap perekonomian masyarakat khususnya dari hasil pemanfaatan limbah alumunium yang ada di sekitar masyarakat peserta pelatihan. Tidak hanya menggantungkan sumber pendapatan yang ada sekarang, tetapi tercipta sumber pendapatan baru baik sebagai pendapatan sampingan maupun sebagai pendapatan utama

Dalam pelaksanaan kegiatan pengabdian kepada masyarakat berupa pelatihan ini melalui beberapa tahapan antara lain

1. Sosialisasi

Dalam hal ini telah dilakukan melalui korespondensi dengan kelompok masyarakat di sekitar Madiun khususnya di Kecamatan Caruban. Dari hasil sosialisasi ini diperoleh 20 peserta yang terdiri dari berbagai latar belakang yang berbeda. Sebagian besar dari peserta adalah perajin kayu karena di daerah Caruban potensi pemanfaatan hasil hutan masih sangat besar. Tetapi ada juga beberapa peserta dari kalangan mahasiswa, juga dari masyarakat usia produktif lainnya.

2. Pelaksanaan Teori

Pelaksanaan teori ini bertujuan untuk memberikan pengetahuan dasar dan teori praktis kepada peserta guna menyamakan persepsi karena sebagian besar berasal dari kelompok masyarakat dengan usaha sebelumnya di bidang bukan logam. Adapun pengetahuan teori yang diberikan antara lain adalah meliputi teori mengenai:

a. Sifat sifat Logam dan non logam

b. Ciri ,Sifat serta Manfaat Aluminium

c. Teknik Pengecoran Aluminium dengan cetakan pasir

Adapun pelaksanaan teori dari kegiatan Pengabdian kepada Masyarakat ini terdokumentasi pada Gambar 1 dan 2 dibawah ini.

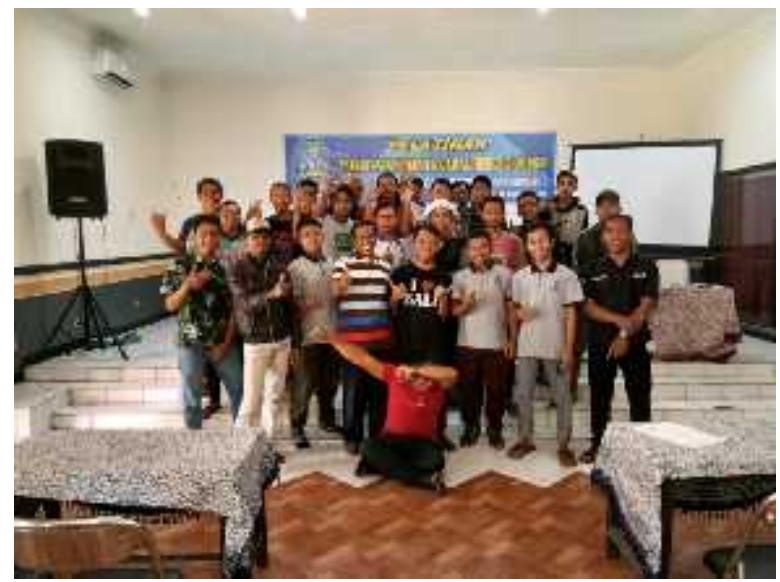

Gambar 1. Peserta Pelatihan bersama Tim Pengabdian Masyarakat 

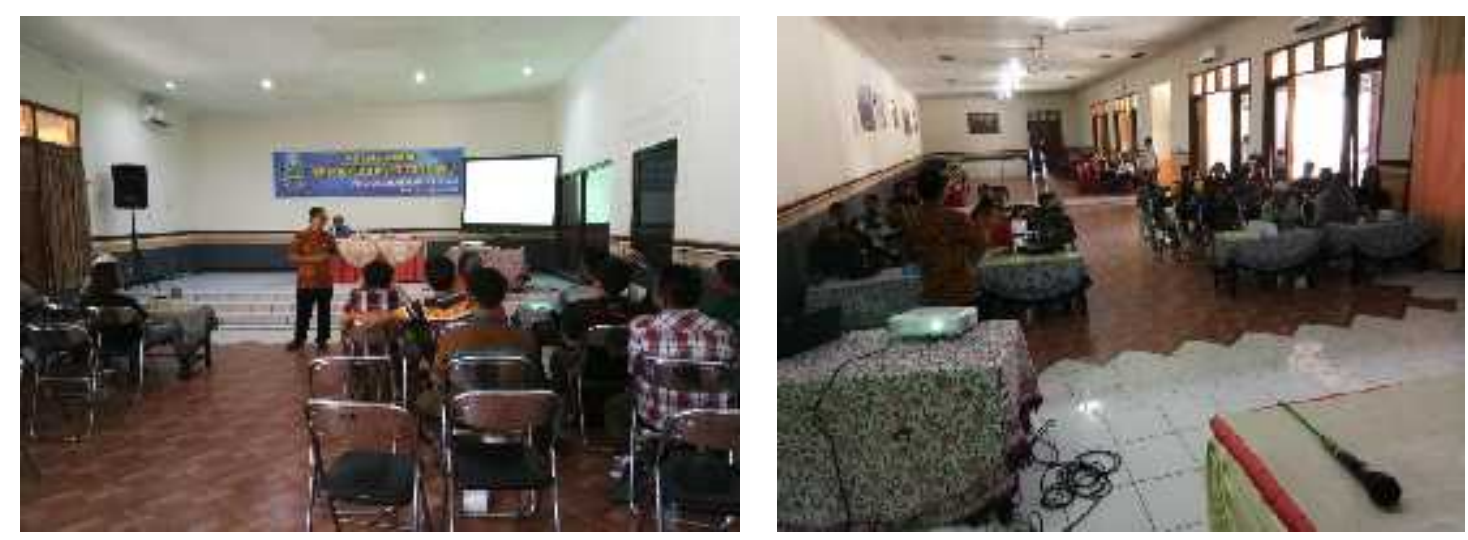

Gambar 2. Tim Pengabdian Masyarakat Memberikan Materi mengenai Logam dan Pengecoran Aluminium

\section{Pelaksanaan Praktek Pengecoran}

Untuk pelaksanaan kegiatan praktek di bagi menjadi 2 (dua) sesi, sesi pertama digunakan untuk memberikan penjelasan mengenai cara membuat cetakan dari pasir resin yang kemudian dilanjutkan dengan mempraktekkan pembuatan pola dari pasir resin oleh masing masing peserta (Gambar 3), termasuk didalamnya adalah proses penyiapan alat alat dan bahan yang diperlukan seperti ditunjukkan Gambar 4.

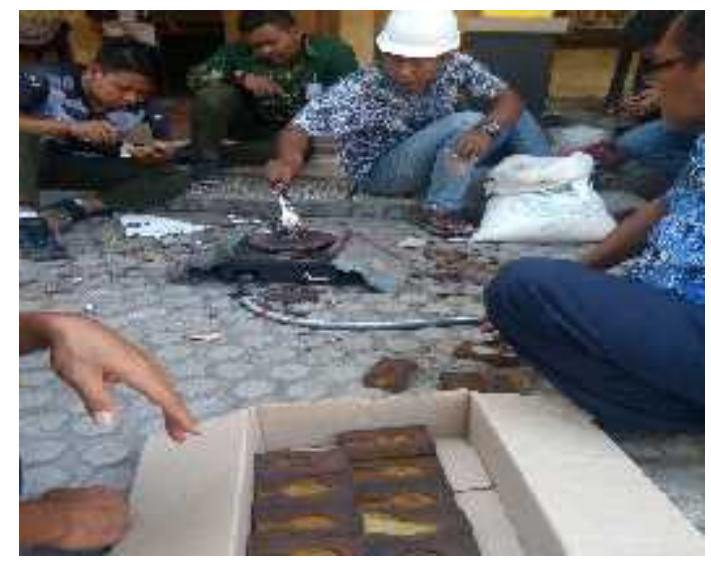

Gambar 3. Tim Pengabdian Masyarakat memberikan panduan dalam membuat pola cetakan dengan pasir resin

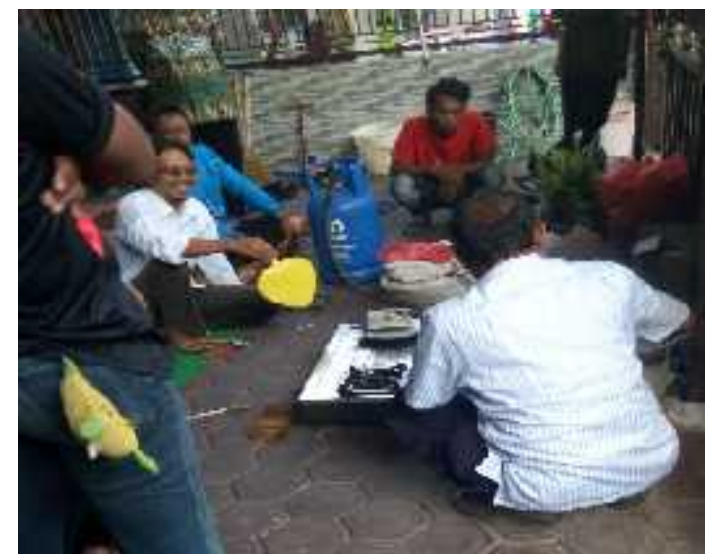

Gambar 4. Persiapan Alat dan Bahan Pengecoran Ulang Alumunium

Pola yang disediakan masih sederhana dengan harapan akan bisa memancing kreasi dari pada peserta untuk dapat membuat dan mendesain sendiri pola pilihan sesuai dengan kreasi dari masing-masing peserta. Untuk tahap awal pola yang di pilihkan berupa sebuah gantungan kunci sederhana yang bertuliskan "Madiun", seperti pada gambar 5 . 


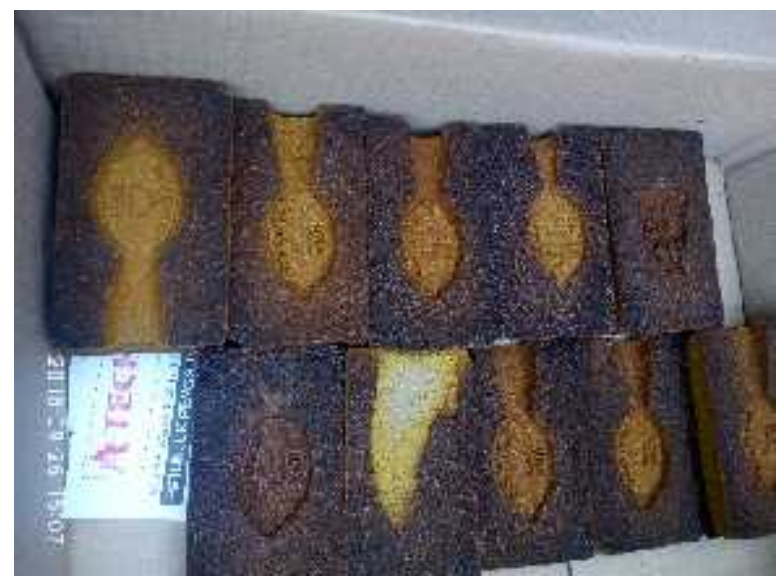

Gambar 5 Hasil pembuatan pola cetakan

Sesi kedua adalah praktek pengecoran dari masing masing peserta, seperti terdokumentasi dalam Gambar 6 dan 7.
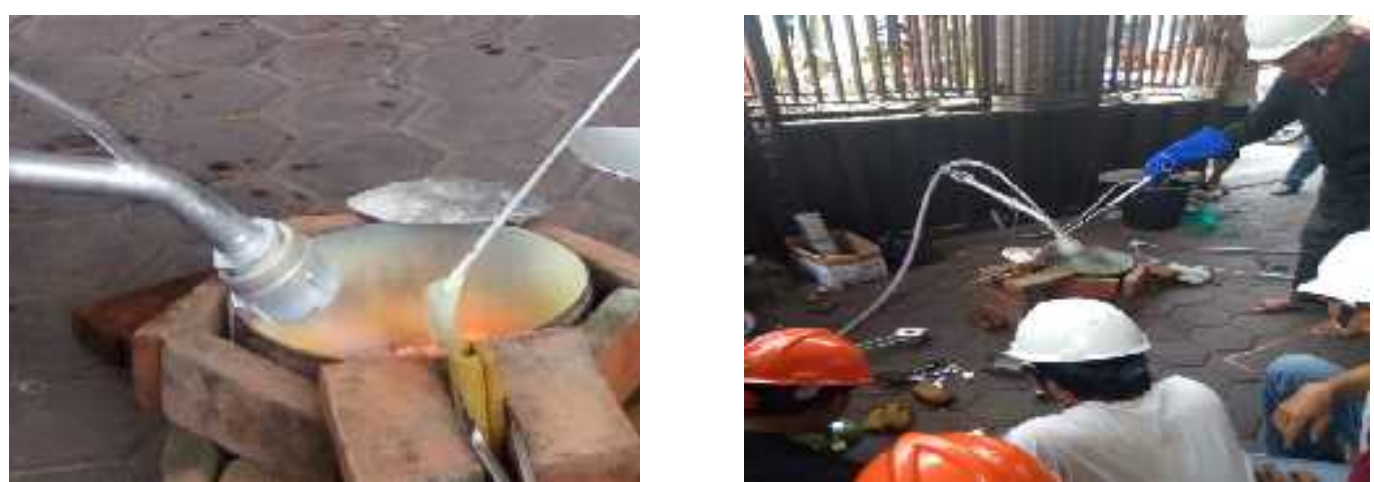

Gambar 6 Proses peleburan aluminium dan proses penuangan ke dalam pola cetakan

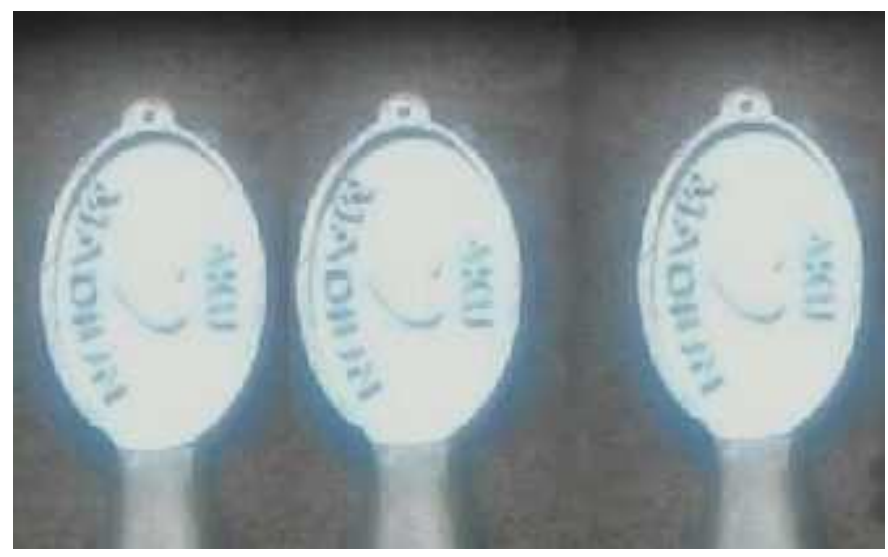

Gambar 7. Hasil pengecoran aluminium

4. Evaluasi

Evaluasi kegiatan dilakukan melalui tanya jawab seputar pelaksanaan kegiatan pelatihan dari tahap penyampaian teori sampai dengan tahap praktek pengecoran oleh 
masing masing peserta. Secara umum peserta pelatihan sudah memahami baik masalah teori maupun praktek, hal ini bisa dilihat dari saat mereka melaksanakan tahap demi tahap dalam pengecoran sederhana ini. Antusiasme dalam berdiskusi tidak hanya mengenai materi pengecoran aluminium saja tetapi sudah berkembang kepada pengecoran dengan material lain.

\section{SIMPULAN}

Dari kegiatan pengabdian ini bisa disimpulan bahwa masyarakat khususnya usia produktif walaupun sudah mempunyai ketrampilan dibidang perkayuan tetapi sangat antusias untuk mengenal dan memahami pengecoran aluminium. Limbah alumunium yang semula tidak bernilai sama sekali, setelah dilakukan pengecoran ulang menjadi produk lain, sedemikian rupa yang dalam kegiatan ini adalah gantungan kunci bisa menambah nilai dan penghasilan masyarakat Kabupaten Madiun.

Pemanfaatan limbah aluminium juga merupakan salah satu solusi untuk mengurangi sampah non organik yang sulit terurai oleh organisme sehingga akan mencemari lingkungan. Para tenaga kerja usia produktif hanya butuh pemahaman serta bimbingan agar mampu mengubah sampah yang tidak bermanfaat menjadi bermanfaat bahkan menghasilkan nilai jual yang bisa menambah penghasilan. Pengecoran aluminium adalah hal baru, tetapi hal ini tidak menjadi kendala berarti ketika mereka sudah mendapat pelatihan teori yang dilanjutkan dengan praktek. Dari hasil pengecoran ini harapannya bisa dikembangkan menjadi bentuk karya yang inovatif dan produktif sehingga akan semakin menambah nilai jual di masyarakat

\section{UCAPAN TERIMA KASIH}

Kami mengucapkan terima kasih kepada semua pihak yang telah mendukung dalam kegiatan pengabdian kepada masyarakat ini, khususnya kepada Dinas Perindustrian dan Perdagangan Propinsi Jawa Timur yang telah memberikan kesempatan kepada kami untuk menjadi nara sumber dalam pelatihan pengecoran aluminium ini.

\section{DAFTAR RUJUKAN}

Warga Kota Madiun Hasilkan 110 Ton Sampah per Hari. https://madiun.solopos.com/read/20190130/516/968631/warga-kota-madiunhasilkan-110-ton-sampah-per-hari. Diakses tanggal 1 Juli 2019.

Jangan Menimbun Kaleng Bekas di dalam Tanah. https://health.detik.com/ulasankhas/d-1539725/jangan-menimbun-kaleng-bekas-di-dalam-tanah. Diakses tanggal 3 Februari 2019

Freya, 2014 "Today is a particular time of fusion between industry and craft, between material and digital" 
Muhammad Fadilah Arofi, Limbah kaleng dan pemanfaatannya. http://mfarofi.blogspot.com/2015/10/limbah-kaleng-dan-pemanfaatanlimbah.html. Diakses 28 Januari 2019

Tri Wahyuni, Jenis Sampah dan Lama Proses Penghancurannya. https://www.cnnindonesia.com/gaya-hidup/20150314083106-255-39061/jenissampah-dan-lama-proses-penghancurannya. Diakses tanggal 27 Januari 2019.

Yudha Manggala P Putra Sampah Kota Madiun Capai 91,1 Ton per Hari https://republika.co.id/berita/nasional/daerah/16/03/16/o4417x284-sampah-kotamadiun-capai-911-ton-per-hari. Diakses tanggal 28 April 2019

Suyitno, S., Salim, U. A., \& Mahardika, M. (2016). Aplikasi Cetakan Permanen untuk Meningkatkan Produksi dan Kualitas Produk IKM Pengecoran Logam Kuningan di Ngawen, Sidokarto, Godean, Yogyakarta. Jurnal Pengabdian kepada Masyarakat (Indonesian Journal of Community Engagement), 2(1), 66-79.

Budiyono, A., \& Widayat, W. (2013). Pemanfaatan Aluminium Skrap Sebagai Bahan Baku Industri Kecil Pengecoran Logam Non Ferro Melalui Perlakuan pada Logam Cair (Solution Treatment) Dengan Rotary Degasser. Sainteknol: Jurnal Sains dan Teknologi, 11(1). 
90 J-Abdipamas, Vol. 3, No. 2 Oktober, 2019 